\title{
SUKSESI KEPEMIMPINAN MUSA KEPADA YOSUA SEBAGAI MODEL REGENERASI KEPEMIMPINAN KRISTEN MASA KINI
}

\author{
Karlitu Dias Markes \\ Sekolah Tinggi Teologi Injili Setia Siau \\ kmarkes@sttissiau.ac.id
}

\begin{abstract}
This research is about the succession model of Moses' leadership to Joshua. The method used is a literature study. The study results indicate that the succession of Moses' leadership to Joshua includes two dimensions, namely the divine dimension and the human dimension. Succession in the divine dimension emphasizes that Moses' relationship and commitment as a senior leader with God were so clear that he was able to know the Vision and Mission of leadership and to know to whom the vision and mission of leadership were continued. In Musa's leadership, the pattern of preparing the younger generation can be seen from two dimensions, namely: preparation in the divine dimension and preparation in the human/human dimension. Preparation in the divine dimension means, in looking for prospective leaders to be prepared, a senior leader should have the ability and sensitivity to understand confirmation from Allah. In addition to preparing a leader in the divine dimension, the Bible also testifies that God with His sovereignty prepares a leader by using humans as a tool to disciple, guide, and train someone to continue God's vision and mission for an institution or church. The process of preparing a prospective leader like this is called preparation in the human/human dimension. Leadership regeneration steps in the human/human dimension include; discipleship, mentoring, and delegation.
\end{abstract}

Keywords: Moses succession to Joshua, leadership succession model, Christian leadership

Abstrak. Penelitian ini diarahkan kepada model suksesi kepemimpinan Musa kepada Yosua. Metode yang digunakan adalah studi pustaka. Hasil penelitian menunjukkan bahwa suksesi kepemimpinan Musa kepada Yosus mencakup dua dimensi yakni dimensi ilahi dan dimensi insani. Suksesi dalam dimensi ilahi menekankan bahwa relasi dan komitmen Musa sebagai pemimpin senior dengan Allah begitu jelas sehingga mampu mengetahui Visi dan Misi kepemimpinan serta menggenal kepada siapa visi dan misi kepemimpinan tersebut dilanjutkan. Dalam kepemimpinan Musa, pola mempersiapkan generasi muda dapat dilihat dari dua dimensi, yakni: persiapan dalam dimensi ilahi dan persiapan dalam dimensi insani/manusiawi. Persiapan dalam dimensi ilahi artinya, dalam mencari calon pemimpin untuk dipersiapkan, maka seorang pemimpin senior seharusnya memiliki kemampuan dan kepekaan dalam memahami konfirmasi dari Allah. Selain persiapan seorang pemimpin dalam dimensi ilahi, Alkitab juga menyaksikan bahwa Allah dengan kedaulatan-Nya mempersiapkan seorang pemimpin dengan menggunakan manusia sebagai alat untuk memuridkan, membimbing, dan melatih seseorang untuk melanjutkan visi dan misi Allah bagi suatu lembaga atau gereja tersebut. Proses mempersiapkan seorang calon pemimpin seperti ini disebut, persiapan dalam dimensi insani/manusiawi. Langkah-langkah regenerasi 
BONAFIDE: Jurnal Teologi dan Pendidikan Kristen

www.jurnal.sttissiau.ac.id/Volume 2/Nomor 2/Desember 2021/hal.214-236

kepemimpinan dalam dimensi insani/manusiawi mencakup; pemuridan, mentoring, dan pendelegasian.

Kata-kata Kunci: Suksesi Musa kepada Yosua, model suksesi kepemimpinan, kepemimpinan Kristen

\section{PENDAHULUAN}

Kepemimpinan sudah dinyatakan sejak masa penciptaan manusia. Ketika Allah menciptakan alam semesta, sesungguhnya Allah telah memberikan suatu amanat kepemimpinan kepada manusia untuk menguasai seluruh ciptaan Tuhan (Kej. 1:28). Amanat tersebut dilaksanakan dalam rencana Allah agar dapat mencapai tujuan Allah bagi seluruh ciptaan-Nya. Alkitab secara eksplisit tidak memberikan suatu definisi atau penjelasan khusus tentang tema kepemimpinan. Walaupun demikian, Alkitab secara umum telah mengungkapkan fakta kepemimpinan.

Dalam Perjanjian Lama dapat ditemukan beberapa bentuk dan sistem kepemimpinan yaitu: kepemimpinan yang bersifat keluarga, marga, klan dan suku (Kejadian 4-9). Kemudian berkembang menjadi Monarki (Kejadian 6-19) yang mana seorang raja sebagai pemimpin. Bentuk kepemimpinan ini kemudian berkembang menjadi model kepemimpinan yang bersifat formal seperti raja, Firaun dan lain-lain (Tomatala 2002b). Dalam Perjanjian Baru, pemahaman kepemimpinan dapat ditemukan dalam pola kepemimpinan Tuhan Yesus dan ajaran-ajaran-Nya. Hal ini dapat dilihat dari ungkapan Yesus yang berkata, “Kepada-Ku telah diberikan segala kuasa di surga dan di bumi” (Mat 28:18). Selain itu, pola kepemimpinan Tuhan Yesus sebagai "nabi-imam-raja" menjadi landasan utama proses kepemimpinan Kristen.(Maedjaja 1995). Surat-surat Paulus 
BONAFIDE: Jurnal Teologi dan Pendidikan Kristen

www.jurnal.sttissiau.ac.id/Volume 2/Nomor 2/Desember 2021/hal.214-236

juga memberikan suatu pola kepemimpinan yang jelas dalam konsep kepemimpinan Kristen. Hal ini dapat dilihat dari konsep "Tubuh Kristus” (1 Kor 12:12-30; Ef. 4:15-16). Konsep ini merupakan landasan yang kuat bagi organisasi Kristen serta fungsi-fungsinya. Konsep ini mengetengahkan suatu kebenaran penting, yaitu adanya kejelasan peran pemimpin dimana disebutkan bahwa "Kristus adalah kepala" hal ini menekankan pentingnya pemimpin dalam kepemimpinan (Tomatala 2002b). Dengan demikian Pemimpin dan kepemimpinan adalah kebutuhan yang sangat mendasar dalam kehidupan manusia.

Perubahan dunia yang begitu cepat memberikan segala macam tantangan yang terus-menerus kepada pemimpin-pemimpin Kristen untuk memacu diri secara kreatif dalam menghadapi berbagai persaingan yang ada. Melihat realitas tersebut, maka kebutuhan suksesi kepemimpinan sangat relevan dengan situasi dunia saat ini. Gereja maupun lembaga-lembaga gerejawi membutuhkan figurfigur pemimpin yang kritis-kreatif, serta realistis dalam memimpin di tengahtengah situasi dunia seperti ini. Seorang pakar kepemimpinan kristen yang bernama Leighton ford menuliskan bahwa: "Pemimpin-pemimpin saat ini sudah seharusnya menyadari betapa pentingnya pengkaderan kepemimpinan bagi pemimpin-pemimpin muda dengan tujuan agar pemimpin-pemimpin muda dapat memimpin lebih seperti Yesus dan memimpin lebih ke arah Yesus". Hal ini berarti proses pengkaderan kepemimpinan kristen harus didasarkan pada pola dan karakter yang alkitabiah. Pola dan karakter kepemimpinan yang alkitabiah itulah sebagai asas-asa dalam pendidikan kepemimpinan kristen. 
BONAFIDE: Jurnal Teologi dan Pendidikan Kristen

www.jurnal.sttissiau.ac.id/Volume 2/Nomor 2/Desember 2021/hal.214-236

Selanjutnya asas-asas kepemimpinan kristen menjadi kebutuhan yang mendesak dalam kehidupan gereja masa kini. Kenyataan yang ada saat ini, polapola suksesi kepemimpinan Kristen dapat dikatakan sudah jauh dari harapan. Praktek suksesi kepemimpinan dalam kehidupan orang percaya saat ini telah direduksi oleh pola-pola kepemimpinan sekuler yang tidak lagi berorientasi pada dimensi alkitabiah yang menjadi standar utama dalam sebuah kepemimpinan Kristen. Realitas di atas mengindikasikan bahwa perhatian terhadap program suksesi kepemimpinan merupakan kebutuhan yang mendasar bagi gereja. Menurut penulis, krisis kepemimpinan ini hanya dapat diatasi oleh seorang pemimpin rohani yang berintegritas dalam aspek rohani, aspek kepribadian, dan aspek sosial. Gereja perlu mempersiapkan generasi muda melalui pendidikan kepemimpinan Kristen untuk menghasilkan figur-figur pemimpin yang kritis, kuat dan teguh pada kebenaran Allah dalam menjalan kepemimpinannya.

Isu tentang suskesi kepemimpinan sudah dikaji oleh banyak peneliti, Mouri Setiawan (pp. 2015) yang menegaskan tugas pemimpin untuk mencari dan menemukan pemimpin baru. Fredy Karel dan Indra Kurniawan menyoroti regenerasi kepemimpinan Musa Kepada Yosua ditinjau dari Kitab Bilangan 27:18-20 (pp.2018). Penelitian ini sendiri lebih berfokus kajian terhadap model suksesi kepemipinan Musa kepada Yosua dan implikasinya bagi pendidikan agama Kristen. 
BONAFIDE: Jurnal Teologi dan Pendidikan Kristen

www.jurnal.sttissiau.ac.id/Volume 2/Nomor 2/Desember 2021/hal.214-236

\section{METODE PENELITIAN}

Penelitian ini dilakukan dengan pendekatan studi pustaka dengan mengelaborasi literatur yang berkaitan dengan topik tentang suksesi kepemimpinan Musa kepada Yosua dan implikasinya dalam pendidikan Kepemimpinan Kristen profil Musa dan kepemimpinannya serta model susksesi kepemimpinan Musa kepada Yosua. Adapun analisis dilakukan dengan bersumber pada beberapa literatur yang diperoleh dari Google Scholar maupun Google. Literatur tersebut dianalisis dengan proses penelaahan yang mendalam kemudian dipahami, dimaknai, dibandingkan serta diuraikan secara sistematis untuk dibahas sesuai kaidah ilmiah yang sistematis. Penelitian ini diharapkan memberikan suatu formula baru pendidikan dan pengembangan kepemimpinan Kristen.

\section{HASIL PENELITIAN}

Dari hasil kajian literatur Alkitab ditemukan bahwa model suksesi kepemimpinan Musa kepada Yosua adalah sebagai berikut: pertama, Musa mempersiapkan Yosua dalam dua dimensi, yaitu; dimensi ilahi dan dimensi insani. Dari dimensi ilahi, Musa mendasarkan pemilihan penerusnya melalui komunikasi yang intensif dengan Tuhan melalui doa (Ulangan 31:2). Musa mendasarkan pilihannya pada petunjuk dan kehendak Tuhan.

Dalam proses komunikasi dengan Tuhan, Musa juga mewujukan kehendak dan rencana Tuhan melalui tindakan yang konkrit. Ini merupakan dimensi insani atau manusiawi dalam proses regenerasi kepemimpinan yang diupayakan oleh Musa. Ia menempuh beberapa strategi. Pertama, pemuridan. Dalam Keluaran 
BONAFIDE: Jurnal Teologi dan Pendidikan Kristen

www.jurnal.sttissiau.ac.id/Volume 2/Nomor 2/Desember 2021/hal.214-236

18:20, menggambarkan suatu penerapan pola pemuridan yang dilakukan Musa sebelum memberikan tanggung jawab sebagai hakim bagi tua-tua Israel.

Kedua, mentoring. Dalam proses mentoring Musa ada beberapa langkah yang dilakukan oleh Musa terhadap Yosua: (1) Musa memberikan pengalaman serta penerapan kepada Yosua. Ia membimbing hingga ke dalam hal yang sangat praktis. Ketika bangsa Israel harus menghadapi bangsa Amalek dalam pertempuran, Musa menjadikan Yosua panglimanya. Ketika dibutuhkan pengintaian dari suku Efraim, Yosua yang diutusnya. Begitupun ketika Musa membutuhkan asisten pribadi, Yosua yang dipilihnya; (2) Musa memberikan dorongan serta penegasan kepada Yosua. Hal ini dilakukan secara berulang kali untuk menegaskan bahwa Yosua memiliki potensi untuk menjadi pemimpin; (3) Musa memberikan kewenangan kepada Yosua. Ketika tiba saatnya, Musa memperkenalkan Yosua di hadapan Israel sebagai pemimpin masa depan (Bilangan 27:18-22; Ulangan 31:7; 34:7). Musa membagikan pengalamanpengalaman rohani yang penting bagi Yosua (Keluaran 24:13; 33:11). Musa juga memberikan tanggung jawab penting (Bilangan 13:16) serta memperlengkapi dan memberi Yosua otoritas sebagai teladan bagi Israel. Dengan demikian, pola atau gaya kepemimpinan Musa inilah yang menjadikan Yosua sebagai pemimpin yang tangguh dalam memimpin Israel ke Kanaan.

Ketiga, pendelegasian tugas. Musa mengembangkan potensi kepemimpinan yang dimiliki Yosua melalui pendelegasian tugas. Upaya Musa ini tampak pada: (1) Musa percaya kepada Yosua sebelum bangsa Israel menerima Yosua sebagai pemimpin mereka; (2) Musa merekomendasikan kepemimpinan 
BONAFIDE: Jurnal Teologi dan Pendidikan Kristen

www.jurnal.sttissiau.ac.id/Volume 2/Nomor 2/Desember 2021/hal.214-236

Yosua kepada bangsa Israel; (3) Musa memberdayakan Yosua untuk mencapai potensinya sebagai seorang pemimpin.

\section{PEMBAHASAN}

\section{Model Pendidikan Kepemimpinan Musa kepada Yosua}

Alkitab secara eksplisit tidak memberikan suatu definisi atau penjelasan khusus tentang regenerasi kepemimpinan. Walaupun demikian, Alkitab secara umum mengungkapkan fakta regenerasi kepemimpinan. Dalam kepemimpinan rohani kemampuan seorang pemimpin tidak hanya dipengaruhi oleh latar belakang hidupnya tetapi ada dimensi yang memiliki peranan dalam proses kepemimpinan tersebut yaitu karya Roh Kudus yang aktif dalam hidup sang pemimpin (Blanckaby dan Blanckaby 2002). Alkitab secara tersirat menyaksikn bahwa Musa merupakan salah satu tokoh pemimpin Israel yang menjadi teladan bagi pemimpin rohani masa kini. Berkenaan dengan proses regenerasi Musa kepada Yosua, penulis menyimpulkan bahwa Yosua dipersiapkan dalam dua dimensi, yaitu; dimensi ilahi dan dimensi insani.

\section{Persiapan Dalam Dimensi Ilahi}

Persiapan dalam dimensi ilahi adalah suatu persiapan seorang pemimpin yang melampaui kemampuan dan pengetahuan manusia. Dalam kepemimpinan Kristen, dimensi ini bersifat sangat fundamental bagi seorang calon pemimpin rohani. Seorang pemimpin senior memiliki kepekaan untuk menangkap konfirmasi Allah dalam memilih calon pemimpin penerus karena persiapan dalam 
BONAFIDE: Jurnal Teologi dan Pendidikan Kristen

www.jurnal.sttissiau.ac.id/Volume 2/Nomor 2/Desember 2021/hal.214-236

dimensi Ilahi bergantung sepenuhnya pada kedaulatan Allah. Sering terjadi seorang pemimpin rohani sudah dipersiapkan oleh Tuhan tanpa ia sendiri mengetahuinya. Tuhan mempersiapkan seseorang justru melalui hal-hal yang sederhana. Jelaslah bahwa secara rohani Tuhan sendirilah yang mencari pemimpin. (Octavianus 1998).

Seorang pemimpin senior juga perlu menyadari bahwa fondasi kedaulatan meliputi kegiatan Allah pada tahun-tahun pembentukan orang itu (calon pemimpin) (Blanckaby dan Blanckaby 2002). Kepemimpinan Kristen berpusat pada Allah. Allah oleh kedaulatan-Nya menetapkan dan memanggil setiap pemimpin kepada tugas dan tanggung jawab kepemimpinan (Tomatala 2002b)

Dalam kepemimpinan Musa dimensi ini mendapatkan perhatian khusus. Hal ini dapat dilihat dari gaya kepemimpinan Musa sebagai pendoa syafaat. Musa tidak hanya menaikkan doa syafaat umat Israel tetapi juga Musa senantiasa bertanya kepada Tuhan mengenai setiap masalah yang dihadapi umat Israel. Berkenaan dengan masalah regenerasi kepemimpinan Musa kepada Yosua, jelas bahwa pengangkatan Yosua menjadi pengganti Musa berdasarkan konfirmasi yang jelas dari Tuhan (Ulangan 31:2).

\section{Persiapan Secara Insani/Manusiawi}

Allah dengan kedaulatan-Nya dapat mempersiapkan seorang pemimpin rohani masa depan. Namun dalam persiapan itu Allah menggunakan manusia sebagai alat untuk memuridkan, membimbing, dan melibatkan seseorang menjadi pemimpin rohani masa depan. Dalam dimensi ini manusia berperan untuk 
BONAFIDE: Jurnal Teologi dan Pendidikan Kristen

www.jurnal.sttissiau.ac.id/Volume 2/Nomor 2/Desember 2021/hal.214-236

mengembangkan potensi kepemimpinan seorang calon pemimpin. Agar program ini dapat terlaksana, maka seorang pemimpin membutuhkan suatu model pelatihan bagi calon-calon pemimpin untuk mengembangkan potensi kepemimpinan sebagai upaya regenerasi kepemimpinan.

Dalam kepemimpinan Musa terdapat beberapa pola bagi proses regenerasi kepemimpinan, antara lain pemuridan, mentoring, dan pendelegasian tugas.

\section{Pemuridan}

Memuridkan adalah suatu proses yang sering dilupakan oleh seorang pemimpin. Padahal, bagi seorang pemimpin, proses ini sangat penting. Memuridkan berarti menyediakan waktu untuk menegur, mengoreksi, menanamkan nilai-nilai luhur dan motivasi (Adipatra 2006). Konsep pemuridan dalam Perjanjian Lama senantiasa dikaitkan dengan membagikan kepada orang lain dengan apa yang telah disampaikan Tuhan.

Dalam pola pemuridan seorang pemimpin berperan sebagai pembina yang senantiasa membina dan mengajarkan hal-hal yang berkenaan dengan prinsipprinsip organisasi tersebut (Moore 1981). Keluaran 18:20, menggambarkan suatu penerapan pola pemuridan yang dilakukan Musa sebelum memberikan tanggung jawab sebagai hakim bagi tua-tua Israel. Melalui pemuridan seorang pemimpin rohani mewariskan tongkat estafet kepemimpinan kepada generasi berikutnya.

Pemuridan merupakan program pertama dalam persiapan untuk pekerjaan Tuhan. Murid tidak bisa dilahirkan tetapi harus dibuat dan dipersiapkan. Dengan demikian maka tugas seorang pemimpin rohani tidak hanya mewariskan 
BONAFIDE: Jurnal Teologi dan Pendidikan Kristen

www.jurnal.sttissiau.ac.id/Volume 2/Nomor 2/Desember 2021/hal.214-236

pengetahuannya melainkan mewariskan seluruh kehidupannya, kepribadiannya, dan teladannya (Octavianus 1997). Dengan demikian, pola pemuridan yang berhasil dalam kepemimpinan rohani ialah ketika murid dibimbing sampai memahami nilai-nilai kepemimpinan rohani yakni kepemimpinan yang melayani.

\section{Mentoring}

Mentoring dari kata mentor yang artinya penasehat atau penolong. Dalam konsep keseluruhan dapat juga disebut sebagai pembimbingan. Pembimbingan berarti suatu kegiatan memberi nasehat, arahan, pertolongan yang terarah dengan integritas yang tinggi sehingga orang lain mengalami kemajuan dan berubah ke arah yang lebih baik dan tepat (Nggebu 2000). Mentoring menyediakan suatu kesempatan untuk hubungan pribadi yang sehat. Hubungan yang mengandung kepeduliaan dan tanggung jawab timbal balik dan saling mempengaruhi (Henry 2001). Proses mentoring dilakukan dengan cara membagi pengalaman hidup dari pemimpin kepada calon pemimpin secara terencana.

Berkenaan konsep mentoring secara eksplisit memang tidak dibahas dalam kisah kepemimpinan Musa, namun dalam proses kepemimpinan Musa menggambarkan konsep mentoring yang diaktualisasikan dalam hubungan Musa dan Yosua. Dalam proses mentoring Musa ada beberapa langkah yang dilakukan oleh Musa terhadap Yosua; Pertama, Musa memberikan pengalaman serta penerapan kepada Yosua. Dalam hal ini, bimbingan terhadap Yosua bukanlah sekedar transfer informasi. Melainkan mencakup pengalaman nyata. Musa membagi kehidupan serta tanggung jawabnya dengan Yosua (Tubagus 2021). 
BONAFIDE: Jurnal Teologi dan Pendidikan Kristen

www.jurnal.sttissiau.ac.id/Volume 2/Nomor 2/Desember 2021/hal.214-236

Ketika bangsa Israel harus menghadapi bangsa Amalek dalam pertempuran, Musa menjadikan Yosua panglimanya. Ketika dibutuhkan pengintaian dari suku Efraim, Yosua yang diutusnya. Ketika Musa membutuhkan asisten pribadi, Yosua yang dipilihnya.

Kedua, Musa memberikan dorongan serta penegasan kepada Yosua. Seorang pemimpin dapat memberikan waktu serta akses untuk mendorong orang yang dibimbingnya. Musa memberikan dorongan secara berulang kali untuk menegaskan bahwa Yosua memiliki potensi untuk menjadi pemimpin.

Ketiga, Musa memberikan kewenangan kepada Yosua. Ketika tiba saatnya, Musa meletakkan tangannya atas Yosua dan secara publik menugaskannya di hadapan bangsa Israel itu dan memberikan kewenangan kepada Yosua (Maxwell 2002). Jadi proses persiapan yang dilakukan oleh Musa kepada Yosua dimulai dari Musa memperkenalkan Yosua di hadapan Israel sebagai pemimpin masa depan (Bilangan 27 : 18 -22; Ulangan 31:7; 34:7). Musa membagikan pengalaman-pengalaman rohani yang penting bagi Yosua (Keluaran 24:13; 33:11). Musa juga memberikan tanggung jawab penting (Bilangan 13:16) serta memperlengkapi dan memberi Yosua otoritas sebagai teladan bagi Israel. Dengan demikian, pola atau gaya kepemimpinan Musa inilah yang menjadikan Yosua sebagai pemimpin yang tangguh dalam memimpin Israel ke Kanaan.

\section{Pendelegasian Tugas}

Seorang pemimpin yang baik menyadari kesanggupan dan keterbatasannya serta meyakini pula akan kesanggupan orang-orang yang 
BONAFIDE: Jurnal Teologi dan Pendidikan Kristen

www.jurnal.sttissiau.ac.id/Volume 2/Nomor 2/Desember 2021/hal.214-236

dipimpin. Tugas seorang pemimpin bukan hanya menunjukkan jalan untuk diikuti oleh orang lain, melainkan sanggup menjadikan orang-orang itu sebagai pemimpin-pemimpin baru, dengan cara melatihnya (mentoring) dan selanjutnya mendelegasikan tugas dan wewenang kepada penggantinya (Yudho 2006). Pendelegasian tugas merupakan faktor yang sangat penting dalam manajemen kepemimpinan.

Salah satu pola pendelegasian yang benar dapat dilihat dalam kepemimpinan Musa (Bil 11:10-17). Seni pendelegasian itu menyangkut orang yang tepat dan pada waktu yang tepat. Seorang pemimpin yang baik menyadari kesanggupan dan keterbatasannya serta meyakini pula akan kesanggupan orangorang yang dipimpinnya. Oleh karena itu pemimpin semestinya belajar melepaskan tugas-tugas tertentu untuk dikerjakan orang-orang yang dipimpinnya (Octavianus 1997). Secara implisit pola pendelegasian sudah diterapkan dalam kepemimpinan Musa dalam memilih tua-tua Israel untuk melaksanakan tugas sebagai hakim (Keluaran $18: 13-11)$. Berkenaan dengan penting delegasi dalam kepemimpinan Kristen, Kenneth O. Gangel menjelaskan;

Bila otoritas didelegasikan maka orang bukan hanya perlu mengharapkan dari penerima otoritas itu tingkat prestasi tertentu yang sepadan dengan tanggung jawab yang diberikan, tetapi juga memberikan kepadanya latihan yang memadai yang akan memungkinkan dia menghasilkan dengan efektif. Dalam pelayanan Kristen dengan pekerjaan yang sukarela, diperlukan banyak subpemimpin (Gangel 1998)

Jadi, pendelegasian membuktikan kematangan pribadi seorang pemimpin.

Dan melalui pendelegasian seorang pemimpin dapat berbuat banyak hal bagi dan melalui banyak orang (Octavianus 1997). Pendelegasian merupakan alat yang 
BONAFIDE: Jurnal Teologi dan Pendidikan Kristen

www.jurnal.sttissiau.ac.id/Volume 2/Nomor 2/Desember 2021/hal.214-236

utama untuk membuka kesempatan bagi lebih banyak pemimpin baru. Kalau pendelegasian dipilih sebagai norma, maka setiap pemimpin dapat menciptakan pemimpin berikutnya. (Hesselbein, Goldsmith, dan Beckhard 1997). Berkenaan dengan pemahaman ini maka penulis menyimpulkan bahwa pendelegasian merupakan suatu pola untuk mencapai proses menciptakan generasi pemimpin muda sehingga proses kepemimpinan berkesinambungan.

Proses regenerasi kepemimpinan Musa kepada Yosua berjalan dengan baik karena adanya kontribusi yang diberikan Musa dalam pemberdayaan potensi kepemimpinan yang dimiliki Yosua. Proses tersebut didasarkan pada; Pertama, Musa percaya kepada Yosua sebelum yang lain percaya kepada Yosua. Ini berarti Musa tidak menunggu sampai bangsa Israel menerima Yosua sebagai pemimpin masa depan Israel melainkan Musa sendiri terlebih dahulu mengakui dan meyakini konfirmasi Allah tentang kepemimpinan Yosua. Kedua, Musa merekomendasikan kepemimpinan Yosua kepada bangsa Israel. Ketiga, Musa memberdayakan Yosua untuk mencapai potensinya sebagai seorang pemimpin. Jadi, Musa sebagai pemimpin senior menyadari diri sebagai alat Tuhan untuk menyukseskan Yosua sebagai pemimpin bangsa Israel.

\section{Keteladanan Musa Di Hadapan Yosua}

\section{Memiliki Kehidupan Rohani yang Baik}

Sebagai senior Musa memang memiliki kehidupan rohani yang baik yang tentu dengan sendirinya diteladani oleh para yunior yang akan menjadi penerusnya. Dalam Ibrani 11:24-29 dikatakan bahwa Musa memiliki iman yang 
BONAFIDE: Jurnal Teologi dan Pendidikan Kristen

www.jurnal.sttissiau.ac.id/Volume 2/Nomor 2/Desember 2021/hal.214-236

teguh. Ia merupakan sebagai saksi iman bagi bangsa Israel. Dalam ayat 25 kalimat "Karena Iman" dalam terjemahan Yunani menggunakan istilah pistei (Noun, Fem, Singl, Datif) (Sutanto 2003b) dari akar kata pisti"/ pistis yang artinya: kepercayaan, iman, kesetiaan, agama, ajaran yang diimani, janji, dan bukti.” (Sutanto 2003a). Secara grammatical istilah pistei menggunakan kasus datif berarti menuntut adanya obyek. Artinya Musa memberikan suatu teladan iman yang sudah terbukti dalam pengalamannya. Bukti iman inilah yang menjadi dasar keyakinan untuk mengambil keputusan-keputusan dalam kepemimpinannya.

Musa juga memiliki panggilan hidup yang jelas dalam Tuhan. Dalam Keluaran 3:10 dikatakan, "Jadi sekarang, pergilah, Aku mengutus engkau kepada Firaun untuk membawa umat-Ku orang Israel, keluar dari Mesir." Kalimat "Aku mengutus engkau" dalam terjemahan bahasa Ibrani we'esyelakana bentuk kata kerja ini menggunakan konyugasi Qal Imperfek dari akar kata syalakh yang artinya: mengirim, menyuruh, melepaskan, mengutus (Sitompul 2002). Allah mengutus Musa sebagai “God's Representatif” yang diperlengkapi dengan "Signs and Wonders" (Keluaran 4:28) untuk membebaskan Israel dari Mesir (Harris, Archer, dan Waltke 1979).

Jika dicermati maka jabatan Musa sebagai utusan Allah ialah sebagai nabi Allah, sebagai duta Allah bagi Firaun dan sekaligus sebagai Imam yang memimpin dan memerintah Israel. Dengan demikian maka salah satu kelebihan Musa sebagai pemimpin yang besar ialah; ia memimpin berdasarkan konfirmasi yang jelas dari Allah. Jadi seorang pemimpin rohani terpanggil dengan konfirmasi yang jelas dari Allah melalui Firman-Nya. 
BONAFIDE: Jurnal Teologi dan Pendidikan Kristen

www.jurnal.sttissiau.ac.id/Volume 2/Nomor 2/Desember 2021/hal.214-236

\section{Memiliki Kepribadian yang Baik}

Kepribadian merupakan salah satu sumber persoalan yang dihadapi oleh seorang pemimpin. Demikian juga salah satu faktor keberhasilan seorang pemimpin turut ditentukan oleh kepribadian (Octavianus 1998). Sebagai pemimpin Musa memiliki sejumlah kepribadian yang baik. Ia adalah seseorang yang sangat lembut hatinya (Keluaran 12:3). Kalimat "sangat lembut hatinya" dalam bahasa Ibrani menggunakan Istilah Anawn (Adv, Mask. Singl), (Owens 1995) dari akar kata Anav yang artinya: poor, afficted, humble, meek (Harris, Archer, dan Waltke 1979). Dalam terjemahan NIV menggunakan istilah "Very humble," sedangkan NKJV menggunakan istilah “Very meek." (New King James Version 2000).

Jadi istilah "Sangat lembut" berkenaan dengan kerendahan hati seseorang yang diwujudkan melalui sikap hidup. Dalam Bilangan 12:3, istilah Anav artinya Very meek, very humble. Pengertian utama dari kata ini ialah kemampuan seseorang untuk rendah hati sebagai usaha pengendalian diri dan bergantung sepenuhnya kepada Tuhan (New King James Version 2000). Jadi, kepribadian Musa yang lemah-lembut merupakan suatu sikap penyangkalan diri dari potensi kesombongan yang dimiliki oleh Musa sebagai pemimpin serta menjalankan tugas kepemimpinnya berdasarkan kehendak Tuhan.

Memiliki Intelektual yang Tinggi (Kisah Para Rasul 7:22)

Dalam ayat ini dituliskan demikian: "Dan Musa dididik dalam segala hikmat orang Mesir, dan ia berkuasa dalam perkataan dan perbuatannya." Istilah 
BONAFIDE: Jurnal Teologi dan Pendidikan Kristen

www.jurnal.sttissiau.ac.id/Volume 2/Nomor 2/Desember 2021/hal.214-236

sofia artinya hikmat atau ilmu. NIV dan NKJV menggunakan istilah "wisdom." Dengan demikian maka dapat dimengerti bahwa hikmat atau ilmu dalam Kisah Para Rasul 7:22 berkenaan dengan kualitas intelektual yang dimiliki oleh Musa melalui didikan di Mesir.

Alkitab menyaksikan dua pengalaman hidup Musa yang mengembangkan pengetahuan dalam kehidupannya sebelum memimpin bangsa Israel yakni; Pertama, Kehidupan di istana Firaun. Putri Firaun mengadopsi Musa dan mempersiapkan Musa untuk hidup layak di istana Firaun. Josephus, seorang sejarahwan menceritakan bahwa Musa diadopsi untuk menjadi ahli waris kerajaan, Musa diasuh untuk sebuah tahta kerajaan.(Meyer 1953). Dalam Kisah Para Rasul 7 : 22 dijelaskan "Musa dididik dalam segala hikmat orang Mesir." Musa diajarkan tatakrama Mesir, Musa dididik di Kuil Matahari dengan mata kuliah yang disebut Hieroglif 101. (Meyer 1953) Musa mulai belajar bahasa Mesir di Kuil itu. Menyelami ilmu alam, ilmu pengobatan, astronomi, kimia, dan hukum. Hampir dapat dipastikan ia mengambil bidang yang berhubungan Badan Pelatihan Pasukan Mesir, belajar perang, taktik pertempuran, dan ia mencoba seni pahat, musik dan seni lukis. Bahkan seluruh literatur tentang dunia Mesir telah diketahuinya. (Swindoll, n.d.). Semua pendidikan dan pelatihan ini merupakan suatu proses reorientasi dalam persiapan untuk tahta kerajaan Mesir.

Kedua, pengalaman Musa di Midian. Pengalaman selama empat puluh tahun di padang gurun Midian menjadi suatu pembelajaran prinsip-prinsip kepemimpinan rohani baginya. Musa taat kepada proses Allah baginya untuk belajar rendah hati, Musa belajar untuk berdiam dan bergantung sepenuhnya 
BONAFIDE: Jurnal Teologi dan Pendidikan Kristen

www.jurnal.sttissiau.ac.id/Volume 2/Nomor 2/Desember 2021/hal.214-236

kepada Allah, Musa belajar mendapatkan dirinya sebagai seorang yang memiliki potensi kepemimpinan dan melalui pengalaman di Midian membuat Musa menjadi seorang pemimpin Rohani yang memiliki visi yang besar yakni pembebasan suatu bangsa. Jadi, pengalaman dan pemahaman yang komperhensif mengenai ilmu pengetahuan dan kerohanian berdampak keberhasilan dalam kepemimpinan Musa.

\section{Memiliki Kehidupan Sosial yang Baik}

Kepemimpinan senantiasa berhubungan dengan individu-indidvidu yang berbeda. Dalam arah itu, seorang pemimpin hendaknya memiliki karakter yang tinggi, pengetahuan yang komprehensif dan kecakapan sosial sehingga menghasilkan efektifitas yang tinggi, efisiensi yang tinggi dan hubungan sosial yang sehat (Tomatala 2002a).

Dalam aspek sosial, terdapat beberapa kepribadian Musa yang erat kaitannya dengan aspek sosial. Pertama, Musa memiliki kepekaaan sosial (Keluaran 2:11). Kata "melihat" dalam terjemahan Ibrani aryw (consec. Qal.Imperf). Kata kerja “u’yara” menggunakan konjugasi Qal Imperfek (future tense). Namun karena kata ini menggunakan preposisi waw consecutif maka memiliki pengertian perfek (Past tense). Sedangkan preposisi waw consecutif sendiri menunjukkan suatu kegiatan yang dilakukan secara berturut-turut dan sungguh-sungguh (Boeker 1993a). Hal ini berarti tindakan Musa melihat saudarasaudaranya bukan hanya terjadi pada suatu kesempatan tertentu melainkan sudah dilakukan berkali-kali. 
BONAFIDE: Jurnal Teologi dan Pendidikan Kristen

www.jurnal.sttissiau.ac.id/Volume 2/Nomor 2/Desember 2021/hal.214-236

Dari analisa tersebut dapat disimpulkan bahwa Musa memiliki solidaritas yang tinggi bagi saudara-saudaranya. Musa tidak hanya memperlihatkan rasa simpatinya tetapi membuktikan perasaan empati terhadap saudara-saudaranya yang disiksa oleh mandor Mesir (ayat 12). Dalam hal ini dapat dipahami bahwa tradisi Yahudi berusaha menampilkan Musa sebagai orang yang mempunyai perhatian kepada bangsanya. (Karris 2002). Dengan demikian, kepekaan sosial adalah salah satu unsur yang terpenting dalam kepemimpinan Kristen.

Kedua, Musa mau menerima nasehat dari orang lain (Keluaran 18:24). Dalam ayat ini mengatakan, "Musa mendengarkan perkataan mertuanya itu dan..." (Keluaran 18:24). Kata "mendengarkan" dalam terjemahan Ibrani menggunakan istilah Wa'yisema (Consec. Qal. Imperf)(Owens 1995) dari akar kata Shama yang artinya: mendengar atau memperhatikan (Sitompul 2002). Dalam BDB diartikan: hear of, Concerning. (Brown 1978).

Kata ini dipakai sebanyak 1050 kali dalam Perjanjian Lama. Pengertian dasar dari istilah Shama dapat berarti; to hear, listen to, pay attention, obey, hear critically. (Harris, Archer, dan Waltke 1979). Jika dicermati dari tata bahasa Ibrani, konjugasi Qal mengindikasikan bahwa tindakan itu dilakukan secara aktif. (Boeker 1993a)Sedangkan bentuk Imperfek mengindikasikan suatu tindakan yang bersifat keakanan (Future) (Boeker 1993b). Namun dengan menggunakan awalan waw consecutive maka bentuk kata itu berubah menjadi tindakan masa lampau (Past tense). Waw consekutive adalah awalan kata kerja untuk suatu kegiatan yang dilakukan secara terus-menerus dan sungguh-sugguh. (Boeker 1993a) Dari analisa 
BONAFIDE: Jurnal Teologi dan Pendidikan Kristen

www.jurnal.sttissiau.ac.id/Volume 2/Nomor 2/Desember 2021/hal.214-236

di atas dapat dimengerti bahwa Musa adalah pemimpin yang mau menerima masukan orang lain.

Ketiga, memberikan kepercayaan kepada pengikut (Keluaran 17:9). Di sini disebutkan bahwa "Musa berkata kepada Yosua, "pilihlah orang-orang bagi kita, lalu keluarlah berperang melawan orang Amalek, besok aku akan berdiri di puncak bukit itu dengan memegang tongkat Allah di tanganku.“ Alkitab memberikan gambaran kepemimpinan Musa yang menerapkan hukum involvement atau hukum keterlibatan.

Dalam Keluaran 17:9 Musa memberikan wewenang kepada Yosua untuk memimpin bangsa Israel melawan bangsa Amalek. Salah satu langkah pemberdayaan potensi adalah memberikan kepercayaan kepada bawahan. Stephen Covey menuliskan bahwa, "memercayai adalah menyampaikan kepada orang lain nilai dan potensi mereka dengan amat jelas, sehingga mereka terilhami untuk melihat sendiri hal itu di dalam diri mereka. Mempercayai orang merupakan akar dari motivasi bahkan bentuk motivasi yang tinggi.“ (Covey 2006).

Alkitab memberikan gambaran kepemimpinan Musa yang menerapkan hukum involvement. Dalam Keluaran 17:9 Musa memberikan wewenang kepada Yosua untuk memimpin bangsa Israel melawan bangsa Amalek. Kewenangan yang diberikan Musa kepada Yosua disertai dengan otoritas untuk mengatur pasukan perang yang dipimpin Yosua. Dalam kepemimpinan rohani, seorang pemimpin perlu menaruh kepercayaan kepada setiap pengikutnya. Pentingnya memberikan kepercayaan kepada pengikut adalah suatu penghargaan kepada pengikutnya. Musa adalah seorang pemimpin rohani melibatkan para 
BONAFIDE: Jurnal Teologi dan Pendidikan Kristen

www.jurnal.sttissiau.ac.id/Volume 2/Nomor 2/Desember 2021/hal.214-236

pengikutnya dalam proses kepemimpinannya. Hal ini sebagai usaha mempersiapkan pemimpin-pemimpin baru untuk melanjutkan kepemimpinannya sehingga terjadi kepemimpinan yang produktif.

\section{KESIMPULAN}

Melalui kajian ini, penulis mengemukakan sebuah pendapat berkenaan dengan pentingnya suksesi kepemimpinan Kristen, antara lain: Pertama, secara Teologis suksesi kepemimpinan Kristen merupakan amanat yang diinisiasi oleh Allah sendiri sekalipun Alkitab tidak secara eksplisit membahas kajian khusus dan sistematis tentang kepemimpinan. Kedua, kesaksian Alkitab mengungkapkan fakta adanya proses suksesi kepemimpinan. Ketiga, Seorang hamba Tuhan sebagai pemimpin rohani perlu memahami bahwa di dalam kepemimpinan rohani seorang pemimpin tidak hanya mengandalkan sumber daya Manusia (SDM) yang dimiliki tetapi juga pemimpin rohani perlu menaruh perhatian kepada Sumber Daya Ilahi yang bersumber dari Allah sendiri.

Suksesi kepemimpinan Musa kepada Yosua merupakan salah satu model regenerasi struktural Alkitabiah yang dapat dijadikan sebagai acuan bagi regenerasi kepemimpinan gereja masa kini. Dalam kepemimpinan Musa, pola mempersiapkan generasi muda dapat dilihat dari dua dimensi, yakni: persiapan dalam dimensi Ilahi dan persiapan dalam dimensi insani/manusiawi. Persiapan dimensi ilahi merupakan suatu persiapan yang bersifat fundamental dalam kepemimpinan Kristen artinya, dalam mencari calon pemimpin untuk dipersiapkan, maka seorang pemimpin senior seharusnya memiliki kemampuan 
BONAFIDE: Jurnal Teologi dan Pendidikan Kristen

www.jurnal.sttissiau.ac.id/Volume 2/Nomor 2/Desember 2021/hal.214-236

dan kepekaan dalam memahami konfirmasi dari Allah. Berikutnya ialah persiapan dalam dimensi insani/manusia artinya, Allah dengan kedaulatan-Nya mempersiapkan seorang pemimpin dengan menggunakan manusia sebagai alat untuk memuridkan, membimbing, dan melatih seseorang untuk melanjutkan visi dan misi Allah bagi suatu lembaga atau gereja tersebut. Langkah-langkah regenerasi kepemimpinan dalam dimensi insani/manusiawi mencakup; pemuridan, mentoring, dan pendelegasian.

Alkitab menyaksikan bahwa regenerasi kepemimpinan telah dilaksanakan dalam kepemimpinan Musa. Proses suksesi kepemimpinan Musa berjalan dengan baik karena adanya relasi dan komunikasi yang baik antara Musa sebagai pemimpin senior dengan Yosua sebagai pemimpin muda yang dipersiapkan. Proses regenerasi kepemimpinan mencakup aspek rohani, aspek kepribadian, dan aspek sosial. Ketiga aspek ini merupakan modal dasar keberhasilan Musa sebagai pemimpin senior dan juga bagi Yosua sebagai pemimpin generasi berikutnya.

Dalam proses suksesi kepemimpinan, seorang pemimpin senior harus mengadakan pembinaan dengan berorientasi pada tiga aspek yang bersifat hakiki yakni: aspek spiritualitas, aspek kepribadian dan aspek sosial. Kepemimpinan rohani yang efektif ialah kepemimpinan yang menjadikan Ketiga aspek ini sebagai tolak ukur dalam kepemimpinan rohani. Pokok pembahasan regenerasi kepemimpinan merupakan suatu topik yang sangat penting dalam suatu organisasi gereja maupun lembaga-lembaga gerejawi. Akbiat dari pelaksanaan program regenerasi secara konsisten dan sistematis maka gereja tetap bertahan selama puluhan tahun. Oleh karena itu para pemimpin memberikan perhatian yang 
BONAFIDE: Jurnal Teologi dan Pendidikan Kristen

www.jurnal.sttissiau.ac.id/Volume 2/Nomor 2/Desember 2021/hal.214-236

khusus pada masalah pengembangan dan perencanaan regenerasi kepemimpinan secara sengaja dan sistematis. secara faktual Alkitab menyaksikan bahwa Yosua dipersiapkan Allah melalui Hamba-Nya Musa untuk menjadi pemimpin masa depan. Persiapan itu mencakup dua dimensi yaitu: dimensi Ilahi dan dimensi Insani/manusiawi.

\section{DAFTAR PUSTAKA}

Adipatra, Budi. 2006. Bukan Sembarang Pemimpin. Yogyakarta: Gloria Graffaa.

Blanckaby, Henry, dan Richard Blanckaby. 2002. Kepemimpinan Rohani. Batam: Gospel Press.

Boeker, T.G.R. 1993a. Bahasa Ibrani Jilid 2. Batu: Institut Injil Indonesia.

—. 1993b. Bahasa Ibrani Jilid I. Batu: Institut Injil Indonesia.

Brown, Francos. 1978. Brown Driver Briggs Gesenius: Hebrew And English Lexicon. Lafayette Indiana.

Covey, Stephen R. 2006. The 8Th Habit: Melampaui Efektifitas, Menggapai Keagungan. Jakarta: Gramedia Pustaka Utama.

Gangel, Keneth O. 1998. Membina Pemimpin Pendidikan Kristen. Malang: Gandum Mas.

Harris, R. Laird, Gleason L. Archer, dan Bruce K. Waltke. 1979. Theological Wordbook of the Old Testament Vol. 1 \& 2. Chicago: The Moody Bible Institut.

Henry, Simon A. 2001. Mentoring: A Tool For Ministry. Saint Louis: Cooperet Publisher House.

Hesselbein, Frances, Marshall Goldsmith, dan Richard Beckhard, ed. 1997. The Leader Of The Future. Jossey-Bass.

Karris, Dianne Bergant \& Robert J. 2002. Tafsir Alkitab Perjanjian Lama. Jakarta: Lembaga Biblika Indonesia.

Maedjaja, Daniel. 1995. Prinsip-Prinsip Dasar Kepemimpinan. Yogyakarta: ANDI Offset.

Maxwell, John C. 2002. 21 Menit Paling Bermakna Dalam Kepemimpinan Sejati. Batam: Interaksara.

Meyer, F. B. 1953. Moses: The servant of God. Grand Rapids: Zondervan Publishing House. 
BONAFIDE: Jurnal Teologi dan Pendidikan Kristen

www.jurnal.sttissiau.ac.id/Volume 2/Nomor 2/Desember 2021/hal.214-236

Moore, Waylon B. 1981. Penggandaan Murid-Murid. Malang: Gandum Mas.

New King James Version. 2000. Michigan: Zondervan Publishing House.

Nggebu, Sostenis. 2000. Mentoring Sebagai Pendampingan Yang Efektif: SAHABAT GEMBALA Edisi Januari. Bandung: Yayasan Kalam Hidup.

Octavianus, Petrus. 1997. Manajemen Dan Kepemimpinan Menurut Wahyu Allah. Batu: Dept. Literatur YPPII. 1998. Peran Dan Pemikiran. Batu: Dept. Literatur YPPII.

Owens, John Joseph. 1995. Analytical Key to the Old Testament. Vol. 1,. Grand Rapids Michigan: Baker Book House.

Sitompul, D. L Baker \& A. A. 2002. Kamus Singkat Ibrani-Indonesia. Jakarta: BPK Gunung Mulia.

Sutanto, Hasan. 2003a. Perjanjian Baru Interlinier Yunani-Indonesia \& Konkordansi PB Jilid 2. Jakarta: LAI.

—. 2003b. Perjanjian Baru Interlinier Yunani-Indonesia \&Konkordansi PB Jilid 1. Jakarta: LAI.

Swindoll, Charles R. n.d. MUSA.

Tomatala, Yakob. 2002a. Kepemimpinan Kristen: Mencari Format Kepemimpinan Gereja Yang Kontekstual di Indonesia. IFTK. Jakarta.

- 2002b. Kepemimpinan Kristen. Jakarta: Institut Filsafat Theologia \& Kepemimpinan Jaffray.

Tubagus, Steven. 2021. Dasar-dasar Pendidikan Agama Kristen. Solok: CV. INSAN CENDEKIA MANDIRI.

Yudho, Bambang. 2006. How To Become A Christian Leader. Yogyakarta: ANDI Offset. 